Sains Malaysiana 48(9)(2019): 1959-1967

http://dx.doi.org/10.17576/jsm-2019-4809-17

\title{
Quality of Life among Colorectal Cancer Screening Patients in Malaysia
}

(Taraf Kehidupan dalam Kalangan Pesakit Saringan Kanser Kolorektum di Malaysia)

\author{
INTAN MELATI ABU BAKAR*, SHARIFA EZAT WAN PUTEH, HALIM ISMAIL, \\ RAJA AFFENDi RaJa Ali \& MUHAMMAD RADZI ABU HASSAN
}

\begin{abstract}
As Malaysia is experiencing a rapid increase in the incidence of colorectal cancer (CRC), the introduction of CRC Screening in Malaysia serves to improve the early CRC detection among Malaysian and its treatment outcome. The present study measured Malaysian's perception on the quality of life ( $Q O L)$ based on screened individuals in Kedah, Malaysia. The study aims to determine QOL among screened individuals based on the CRC screening modalities available in Malaysia. A cross sectional study was conducted from March 2016 to April 2017 in a public tertiary hospital and a district health clinic in the state of Kedah. Three hundred and thirty respondents aged 40 to 70 years old were asked to fill-up a self-reported health survey questionnaire comprised of 36 itemised questions (SF-36). The mean age of respondents was $58.75 \pm 7.53$ years with $52.7 \%$ of respondents being male and $47.3 \%$ female. The majority of respondents have underlying medical illness. Mean health utility's score in CRC screening IFOBT's only modality was higher compare to other modalities 0.85 (ANOVA F=21.505, p<0.001). For the Physical Composite Score (PCS), IFOBT's only modality also had a higher mean score compared to other modalities of 56.64 (ANOVA $F=19.655, \mathrm{p}<0.001$ ) in addition to the Mental Composite Score (MCS) 56.37 (ANOVA F=12.033, p<0.001). The CRC screening via IFOBT's only modality had better QOL in health utility, physical health and mental health compared to other modalities. Therefore, the CRC screening program is essential in preserving the QOL of Malaysian population.
\end{abstract}

Keywords: CRC screening; QOL; SF-36

\section{ABSTRAK}

Malaysia mengalami peningkatan mendadak insiden kanser kolorektal (CRC), pengenalan saringan CRC di Malaysia berfungsi untuk meningkatkan pengesanan awal CRC dalam kalangan rakyat Malaysia dan hasil rawatannya. Kajian ini mengukur persepsi masyarakat Malaysia terhadap kualiti hidup (QOL) berdasarkan individu yang disaring di Kedah, Malaysia. Kajian ini bertujuan untuk menentukan QOL dalam kalangan individu yang disaring berdasarkan modaliti pemeriksaan CRC yang terdapat di Malaysia. Kajian rentas lintang telah dijalankan dari Mac 2016 hingga April 2017 di sebuah hospital awam dan sebuah klinik kesihatan di Kedah. Tiga ratus tiga puluh responden yang berumur 40 hingga 70 tahun terlibat dalam soal selidik kesihatan diri yang mengandungi 36 soalan terperinci (SF-36). Purata umur responden ialah $58.75 \pm 7.53$ tahun dengan $52.7 \%$ responden lelaki dan $47.3 \%$ perempuan. Majoriti responden mempunyai masalah perubatan. Purata skor utiliti kesihatan dalam pemeriksaan CRC modaliti IFOBT sahaja adalah lebih tinggi berbanding modaliti lain 0.85 (ANOVA F = 21.505, p <0.001). Bagi Skor Komposit Fizikal (PCS), modaliti IFOBT juga mempunyai skor min yang lebih tinggi berbanding dengan modaliti lain $56.64($ ANOVA F $=19.655, \mathrm{p}<0.001)$ sebagai tambahan kepada Skor Komposit Mental (MCS) 56.37 (ANOVA F = 12.033, p <0.001). Pemeriksaan CRC melalui modaliti IFOBT sahaja mempunyai QOL yang lebih baik dalam utiliti kesihatan, kesihatan fizikal dan kesihatan mental berbanding modaliti lain. Oleh itu, program saringan CRC adalah penting dalam memelihara QOL penduduk Malaysia.

Kata kunci: QOL; saringan CRC; SF-36

\section{INTRODUCTION}

Colorectal cancer $(\mathrm{CRC})$ is one of the most common cancer in the world. It is the fourth leading cause of cancer-related death worldwide (International Agency for Research on Cancer World Health Organization 2014) and third most common cancer in the USA (American Cancer Society 2013). The incidence of CRC is showing an increasing trend in many countries as well as in the Asian region (Béjar et al. 2012; Sung et al. 2008). In Malaysia, CRC is the second most frequently detected cancer after breast cancer in women, and men. It is also the second most common type of cancer after trachea, bronchus and lung cancer (National Cancer Registry Malaysia 2011). The increasing trend of CRC incidence in Asia and many other economic transition countries (Center et al. 2009) prompts a more effective screening program as well as comprehensive treatment of CRC that includes consideration of patients' quality of life (QOL). The rising incidence of CRC in Asia has increased the burden in public health management. Despite the situation, most Asian populations are not 
aware of the growing problem of CRC. There is low public awareness and little health authority support for CRC screening in Asia (Sung et al. 2008). CRC preventive activities among the primary care providers are still poor in Malaysia. This may be related to the lack of availability of the test in the primary care, poor public awareness and understanding the importance of CRC screening among patients (Norwati et al. 2014). It has resulted in inadequate allocation of resources for CRC screening involving fecal occult blood testing and colonoscopy, resulting in patient being presented for treatment at an advance stage of CRC. Effectiveness of CRC screening programs and advances in treatment, especially in developed countries, has resulted in an increasing number of CRC survivors, as the disease can be cured and patients can survive longer with the disease (Shaukat et al. 2013). Therefore, screening for CRC should be made a national health priority in countries in Asia (Ng \& Wong 2013). Within Asia, only Japan, Taiwan and Korea implement CRC screening as a national policy (Hyodo et al. 2010). Assessment of QOL of CRC screened individuals is important for the community as well as health care providers because the results can guide the policymakers on the appropriate policy action related to CRC screening program.

Although QOL is a subjective perception of CRC's screened individual health status in general, it may influence the policymaker in health care system to emphasize on CRC screening for the Malaysian population. The QOL of the population is an important part of the health economy. Understanding the QOL is essential in health care planning, where monetary measures are not easy to use. Most decisions on investing or treatment are closely related to the QOL of a patient. The usage of patient-reported questionnaire has become a standard practice for assessing QOL. The short form 36 health survey questionnaire (SF36) is a multidomain structured questionnaire applicable across a range of health status to assess QOL in general and widely used (Imran \& Ismail 2010). It incorporates eight domains consisting of thirty-six items. The eight domains are: physical functioning, role limitations due to physical health, role limitations due to emotional problem, energy/fatigue, emotional well-being, social functioning, pain and general health. Scores achieved represented the health status in two dimensions which are physical and mental (Brazier et al. 1992)validity, and reliability of the short form 36 health survey questionnaire (SF-36. This Malay version questionnaire has been validated for the usage in asthmatic patient and nationwide household community survey in Malaysia (Sararaks et al. 2005). SF-36 questionnaire has also been used to assess the generic quality of cancer patients' life in Malaysia (Ezat \& Aljunid 2010; Redhwan et al. 2008). In Malaysia, there is limited data on QOL among the community undergoing health screening, especially a new CRC screening program. Therefore, this study attempts to describe QOL among CRC screened individuals according to CRC screening modalities available in Malaysia and to compare the QOL among different modalities.

\section{MATERIALS AND METHODS}

This was a cross-sectional study conducted between March 2016 and January 2017 comprising of 330 participating respondents from a public tertiary level hospital and a health clinic. Purposive sampling method was used in choosing the hospital and the health clinic because they are among the active pioneer of CRC screening program in Malaysia and are easily accessible. After receiving ethical approval from these institutions, as well as from the Ministry of Health of Malaysia, universal sampling was done in which all patients attending the health clinic and patients from the daycare center that underwent the three modalities of CRC screening (1-IFOBT only, 2-IFOBT and colonoscopy and 3 -colonoscopy only) were chosen. Eligibility criteria were patients over 40 to 70 years of age with no mental health problems. Informed consent to participate in the study was obtained from patients prior to the guided, face-to-face interview conducted by trained interviewers.

The SF-36 (version 2) is a questionnaire with 8 domains that consist of 36 items of questions in English and Malay version. The 8 domains are: physical functioning (10 items), role limitations due to physical health (4 items), role limitations due to emotional problem ( 3 items), energy/ fatigue (4 items), emotional well-being ( 5 items), social functioning ( 2 items), pain ( 2 items) and general health (5 items). Scores can be produced through a two-step process. First, pre-coded numeric values are recorded per the score key. All items are scored so that a high score defines as more favorable health status with each item is scored on a range from 0 to 100 . This represents the percentage of total possible score achieved. In step 2, items in the same scale are averaged together to create the 8 scale scores. The missing data will not be taken into account when calculating the scale scores. Therefore, the scale scores representing the average for all items in the scale that the respondents answered a high score for health status represents a higher level of QOL, thus depicting a higher level of function (RAND Medical Outcome Study 1992).

Respondents' sociodemographic profiles included age, gender, ethnicity, educational level and occupation, as well as the stages of disease. SPSS version 21 was used to analyze the data using a power of study of $80 \%$ and an alpha error of less than the value of 0.05 to be considered as statistically significant. Descriptive statistics were used to describe the result for sociodemographic characteristics of the respondents and scales in the SF 36. All continuous variables were checked for normality through Kolmogorov-Smirnov analysis. Independent sample $t$-test and analysis of variance (ANOVA) can be used to determine whether there were any significant differences in the mean of each SF 36 score across CRC screening modalities and other independents.

\section{RESULTS}

A total of 330 respondents were included in the preliminary report: $110(33.3 \%)$ from health clinic and $220(66.7 \%)$ from 
the public tertiary hospital consisting of 110 respondents from each CRC screening modality. We obtained a $100 \%$ response rate among respondents who willingly participated in this research (Table 1).

\section{SOCIODEMOGRAPHIC PROFILE}

The mean age of respondents was $58.75 \pm 7.53$ years (range: 55-59). The majority of the respondents were 65-69 years old $(28.2 \%)$. The mean age of male and female respondents was similar, with a mean age for male respondents of 60.01 years $(\mathrm{SD} \pm 7.14)$ and a slightly younger mean age for females of 57.35 years ( $\mathrm{SD} \pm 7.73)$. The age difference was significant $(\mathrm{t}=3.247 ; p=0.001)$.

The mean age of respondents in IFOBT's only modality was 60.76 ( $\mathrm{SD} \pm 6.32$ ) years, for IFOBT and colonoscopy modality it was 57.67 ( $\mathrm{SD} \pm 6.37$ ) and for colonoscopy's only modality was 57.83 ( $\mathrm{SD} \pm 9.20)$; these differences were significance (ANOVA F $=6.06 p=0.003$ ). This result shows that respondents in IFOBT only modality are in an older age group. Other sociodemographic characteristics of respondents, such as gender, ethnicity, level of education, marital status, working status, health status and symptoms presented are shown in Table 2.

TABLE 1. Sociodemographic characteristics of 330 respondents

\begin{tabular}{|c|c|c|}
\hline Variable & $\mathrm{n}$ & $\%$ \\
\hline \multicolumn{3}{|l|}{ Gender } \\
\hline Male & 174 & 52.7 \\
\hline Female & 156 & 47.3 \\
\hline \multicolumn{3}{|l|}{ Ethnic group } \\
\hline Malay & 223 & 67.6 \\
\hline Chinese & 89 & 27.0 \\
\hline Indian & 14 & 4.2 \\
\hline Others & 4 & 1.2 \\
\hline \multicolumn{3}{|l|}{ Education level } \\
\hline Not schooling & 8 & 2.4 \\
\hline Primary & 87 & 26.4 \\
\hline Secondary & 183 & 55.5 \\
\hline Tertiary & 52 & 15.8 \\
\hline \multicolumn{3}{|l|}{ Marital status } \\
\hline Single & 13 & 3.9 \\
\hline Married & 285 & 86.4 \\
\hline Divorcee & 7 & 2.1 \\
\hline Widower & 25 & 7.6 \\
\hline Working Status & 124 & 37.6 \\
\hline Yes & 206 & 62.4 \\
\hline \multicolumn{3}{|l|}{ No } \\
\hline Medical Illness & 248 & 75.2 \\
\hline Yes & 82 & 24.8 \\
\hline \multicolumn{3}{|l|}{ No } \\
\hline \multicolumn{3}{|l|}{ Symptoms } \\
\hline Yes & 171 & 51.8 \\
\hline No & 159 & 48.2 \\
\hline
\end{tabular}

There were $52.7 \%$ male respondents and $47.3 \%$ female respondents in this study. The national population ratio showed males are more than female in Malaysia, which could explain the higher percentage seen in men. In terms of gender distribution, there is a significant difference in the gender distribution across all age groups $\left(x^{2}=12.66\right.$; $p$ $=0.03)$ but not significant across ethnic groups $\left(x^{2}=3.19\right.$; $p=0.07)$

Ethnic distribution among respondents is reflective of the Malaysian population in general: $67.6 \%$ Malay, $27.0 \%$ Chinese, $4.2 \%$ Indian and $1.2 \%$ of other ethnics, such as Iban. Patients of Malay ethnicity constituted $63.6 \%$ of IFOBT only modality; as well as the majority of IFOBT and colonoscopy modality $(66.4 \%)$ and colonoscopy only modality $(72.7 \%)$.

For the education level of the respondents, 55.5\% had up to secondary school level education. There was a significant difference in the ethnic distribution among respondents' levels of education $\left(x^{2}=19.82 ; p<0.01\right)$. For marital status, $86.4 \%$ are married.

In terms of stages of underlying medical illness, $75.2 \%$ had underlying medical illness. There was a significant difference in the medical illness across the age group $\left(x^{2}=\right.$ $30.90 ; p<0.01)$. For the presence of symptoms, $51.8 \%$ had symptoms. These differences were significant across the age group $\left(x^{2}=20.05 ; p<0.01\right)$ and among CRC screening modalities $\left(x^{2}=142.52 ; p<0.01\right)$.

\section{QUALITY OF LIFE}

Respondents' QOL was measured using the SF 36 questionnaire, which constituted eight subdomains scores and two domains scores. Normality checks for all scores indicated that all of the scales measured were normally distributed. Therefore, the analysis of QOL data mainly uses parametric statistical analysis.

\section{THE SF-36 SCORES ACCORDING TO CRC SCREENING MODALITIES}

For IFOBT only modality, the average score for the subdomains were more than 85 with five subdomains showed an excellent level (an average score of more than 90), which are physical functions (91.45), physical health limitation (91.59), mental health constraints (91.21), social function (93.98) and pain (90.23). Meanwhile, other subdomains average score was less than 90, energy and fitness (85.85), mental health (85.77) and general health (85.35). Overall, the average physical composite score (56.64) and average composite score (56.36) showed a moderate inability rate.

For IFOBT and colonoscopy modality, the average scores for subdomains were more than 85 with five subdomains showed a good level at an average score of more than 80 . The four subdomains are physical functions (80.28), physical health limitation (83.13), mental health constraints (84.77) and social function (84.66). Meanwhile, energy and fitness (73.92), mental health (78.64). pain (79.76) and general health (75.22) are at a fair level. 
TABLE 2. Sociodemographic characteristics according to CRC screening modalities

\begin{tabular}{|c|c|c|c|c|}
\hline \multicolumn{2}{|c|}{ Variable } & $\frac{\text { IFOBT only }}{\mathrm{n}(\%) \text { mean }(\mathrm{SD})}$ & $\frac{\text { IFOBT dan colonoscopy }}{\mathrm{n}(\%) \text { mean }(\mathrm{SD})}$ & $\begin{array}{c}\text { Colonoscopy only } \\
\text { n }(\%) \text { mean }(\mathrm{SD})\end{array}$ \\
\hline Age (years old) & & $60.76(6.32)$ & $57.67(6.37)$ & $57.83(9.20)$ \\
\hline & $\begin{array}{l}40-44 \\
45-49 \\
50-54 \\
55-59 \\
60-64 \\
65-69\end{array}$ & $\begin{array}{c}1(0.9) \\
0(0) \\
22(20.0) \\
19(17.3) \\
25(22.7) \\
43(39.1)\end{array}$ & $\begin{array}{c}2(1.8) \\
7(6.4) \\
30(27.3) \\
25(22.7) \\
29(26.4) \\
17(15.5)\end{array}$ & $\begin{array}{c}15(13.6) \\
11(10.0) \\
8(7.3) \\
19(17.3) \\
24(21.8) \\
33(30.0)\end{array}$ \\
\hline Gender & $\begin{array}{l}\text { Male } \\
\text { Female }\end{array}$ & $\begin{array}{l}64(58.2) \\
46(41.8)\end{array}$ & $\begin{array}{l}54(49.1) \\
56(50.9)\end{array}$ & $\begin{array}{l}56(50.9) \\
54(49.1)\end{array}$ \\
\hline Ethnic & $\begin{array}{l}\text { Malay } \\
\text { Chinese } \\
\text { Indian } \\
\text { Others }\end{array}$ & $\begin{array}{c}70(63.6) \\
35(31.8) \\
4(3.6) \\
1(0.9)\end{array}$ & $\begin{array}{c}73(66.4) \\
33(30.0) \\
3(2.7) \\
1(0.9)\end{array}$ & $\begin{array}{c}80(72.7) \\
21(19.1) \\
7(6.4) \\
2(1.8)\end{array}$ \\
\hline Educational status & $\begin{array}{l}\text { Non } \\
\text { Primary } \\
\text { Secondary } \\
\text { Tertiary }\end{array}$ & $\begin{array}{c}3(2.7) \\
20(18.2) \\
66(60.0) \\
21(19.1)\end{array}$ & $\begin{array}{c}2(1.8) \\
33(30.0) \\
63(57.3) \\
12(10.9)\end{array}$ & $\begin{array}{c}3(2.7) \\
34(30.9) \\
54(49.1) \\
19(17.3)\end{array}$ \\
\hline Marital Status & $\begin{array}{l}\text { Single } \\
\text { Married } \\
\text { Divorcee } \\
\text { Widow }\end{array}$ & $\begin{array}{c}8(7.3) \\
92(83.6) \\
4(3.6) \\
6(5.5)\end{array}$ & $\begin{array}{c}3(2.7) \\
95(86.4) \\
1(0.9) \\
11(10.0)\end{array}$ & $\begin{array}{c}2(1.8) \\
98(89.1) \\
2(1.8) \\
8(7.3)\end{array}$ \\
\hline Medical Illness & $\begin{array}{l}\text { Yes } \\
\text { No }\end{array}$ & $\begin{array}{l}79(71.8) \\
31(28.2)\end{array}$ & $\begin{array}{l}86(78.2) \\
24(21.8)\end{array}$ & $\begin{array}{l}83(75.5) \\
27(24.5)\end{array}$ \\
\hline Symptoms & $\begin{array}{l}\text { Yes } \\
\text { No }\end{array}$ & $\begin{array}{l}29(26.4) \\
81(73.6)\end{array}$ & $\begin{array}{l}34(30.9) \\
76(69.1)\end{array}$ & $\begin{array}{l}108(98.2) \\
2(1.8)\end{array}$ \\
\hline
\end{tabular}

TABLE 3. Respondents' mean score through SF- 36 questionnaire

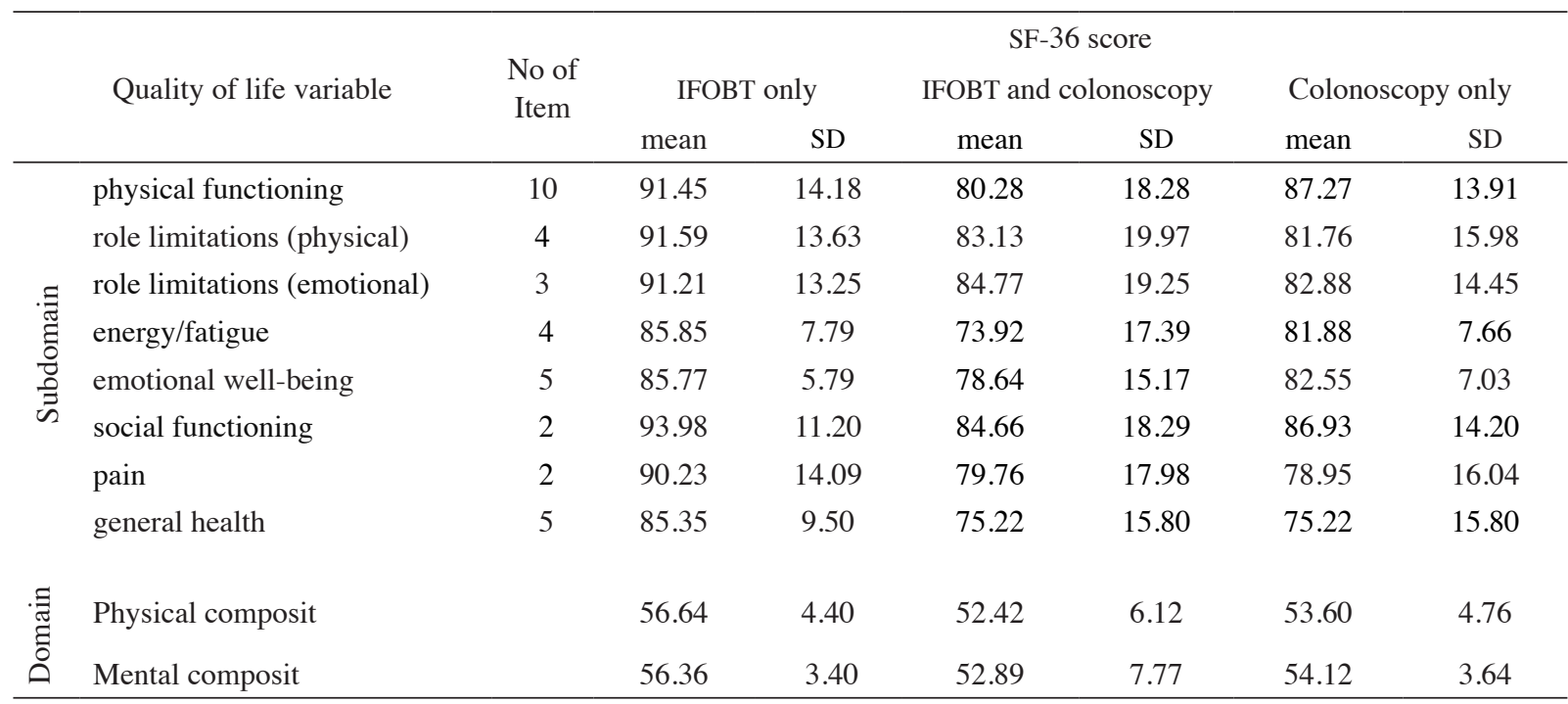

Overall, the average physical composite score (52.42) and average mental composite score (52.89) showed relatively low incapability compared to the IFOBT modality only.

For the colonoscopy only modality, the average score for subdomains were more than 85 with six subdomains have an average score of above 80 . The six subdomains were physical functions (87.27), limited physical health (81.76), mental health constraints (82.88), energy and fitness (81.88), mental health and (82.55) social function (86.93). While, pain (78.95) and general health (75.22) are at a fair level. Overall, the average PCS (53.60) and average mental composite score (54.12) showed lower 
incapacity than IFOBT only modality but higher than IFOBT and colonoscopy modality (Table 3 ).

\section{ANALYSIS SF-36 (PHYSICAL COMPOSITE SCORES, MENTAL COMPOSITE SCORES AND HEALTH UTILITY SCORES) ACCORDING ON CRC SCREENING}

The physical composite score shows the relationship between the modality, IFOBT scored 56.64 followed by colonoscopy (53.60) and IFOBT and colonoscopy (52.42). Using the ANOVA analysis, the mean differences between modalities were significant $(\mathrm{F}=19.655, p<0.0001)$ (Table $4)$. It showed physical quality of life for respondents of IFOBT only better than colonoscopy only and followed by IFOBT and colonoscopy.

The mental composite score also shows the relationship between modalities, IFOBT scored 56.37 followed by colonoscopy only (54.12) and IFOBT and colonoscopy (52.89). Using ANOVA analysis, the average differences between the modalities were significant $(\mathrm{F}=12.033, p$ $<0.0001$ ) (Table 4). This showed the same results as PCS showing the quality of mental life for IFOBT only screening responders better than colonoscopy only and followed by IFOBT and colonoscopy modality.

The health utility's score of CRC screening modalities is obtained through the SF6D score in SF 36 . Health utility scores also show similarity between the modalities, IFOBT only scored 0.850 followed by IFOBT and colonoscopy $(0.772)$ and colonoscopy only (0.762). Using ANOVA analysis, the mean differences between modalities were significant $(\mathrm{F}=21.505, p<0.0001)$ (Table 5). As well as PCS and MCS, health utility scores indicated the health utility quality for the respondents of IFOBT only modality better than colonoscopy only and followed by IFOBT and colonoscopy.

\section{DISCUSSION}

CRC is a public health problem in Malaysia as it is the highest cancer for men and the second highest for women (Hassan et al. 2014). Therefore, CRC screening is necessary in $\mathrm{CRC}$ prevention through detection and the removal of precancerous growths and early stage diagnosis (American Cancer Society 2013). There are three CRC screening modalities implemented in Malaysia at an early stage as there are constraints in technology, facility, human resources and financial factors. Those three modalities of the CRC screening program are involved in this study.

The CRC screening program was carried out by voluntary healthcare customers. Therefore, there are several factors that prevent the effectiveness of the CRC screening program. The results of the previous study showed that $35.2 \%$ of the customers were shy, $30.0 \%$ were uncomfortable and $11.2 \%$ did not receive advice from the healthcare workers to undergo the tests (Yusoff et al. 2012). In addition, a previous study have shown that there are factors such as demographic backgrounds that affect the compliance of the CRC screening program (Hassan et al. 2016)
This study shown male respondents $(52.7 \%)$ exceeded female respondents $(47.3 \%)$. This situation was consistent with the male and female ratio in Malaysia as a total of 107 men to 100 women for the estimated population of Malaysia in 2016 (Department of Statistics Malaysia 2016). However, according to CRC screening modality groups, the number of males exceeds the number of females for the groups of IFOBT only and colonoscopy only. Meanwhile, the number of women exceeds the number of men in IFOBT and colonoscopy modality. There were previous studies involving countries such as Scotland, England and France which showed that women are more likely to undergo CRC screening tests (Leuraud et al. 2013; Logan et al. 2012; Moss et al. 2012; Steele et al. 2010). There was also local studies on CRC screening that women were more likely to have CRC screenings (Hassan et al. 2016).

In view of ethnicity, majority of respondents were Malays followed by Chinese, Indian and Others. This situation is inconsistent with the CRC incidence in Malaysia which states that the incidence by age group is highest among Chinese (27.4/100000), followed by Malays (19.0/100000) and Indians (17.6/100000) (Hassan et al. 2014). However, it was consistent with the location of research facilities that had the majority of healthcare clients among Malays followed by China, India and Others. According to the NHMS 2015 volume III report, the majority of Malays and Indians chose public health services for any health care including dental treatment. Meanwhile, the majority of Chinese choose to seek private sector health services for all treatments except major surgery (Institute of Health System Research 2015). The Chinese tendency of healthcare in the private sector also influenced as this study is only involving the public health service facilities. According to the National Statistics Department's report, it was estimated that the ethnic group breakdowns in Malaysia were as follows; Malays $68.6 \%$, followed by Chinese $23.4 \%$, Indians $7.0 \%$ and others $1.0 \%$ (Department of Statistics Malaysia 2016). This estimated breakdown of ethnic groups is consistent with the ethnic breakdown in this study.

The majority of respondents' education in this study was at the secondary level followed by primary and higher education. The adult literacy rate of Malaysia showed an increase from the previous years from $69.52 \%$ (1980) to $88.69 \%$ (2000) to $93.12 \%$ (2010) (UNESCO Institute for Statistics 2015). Due to the limited selection of criteria of respondents to the age of 40 to 69 , these groups who are in still their childhood, the implementation and awareness of education were still at early stage. Therefore, the majority of respondents' education were secondary level and some respondents at primary level. Meanwhile, highly educated respondents reflect the impact of the increasing literacy level and the development of Malaysia education system and research conducted in urban areas in the northern region of Peninsular Malaysia. This study did not show significant differences of literacy rates in Malaysia for 2015 i.e. $94.64 \%$ for the population of over 15 years (UNESCO Institution for statistics), and there are still numbers of respondents who never have formal education (2.4\%). 


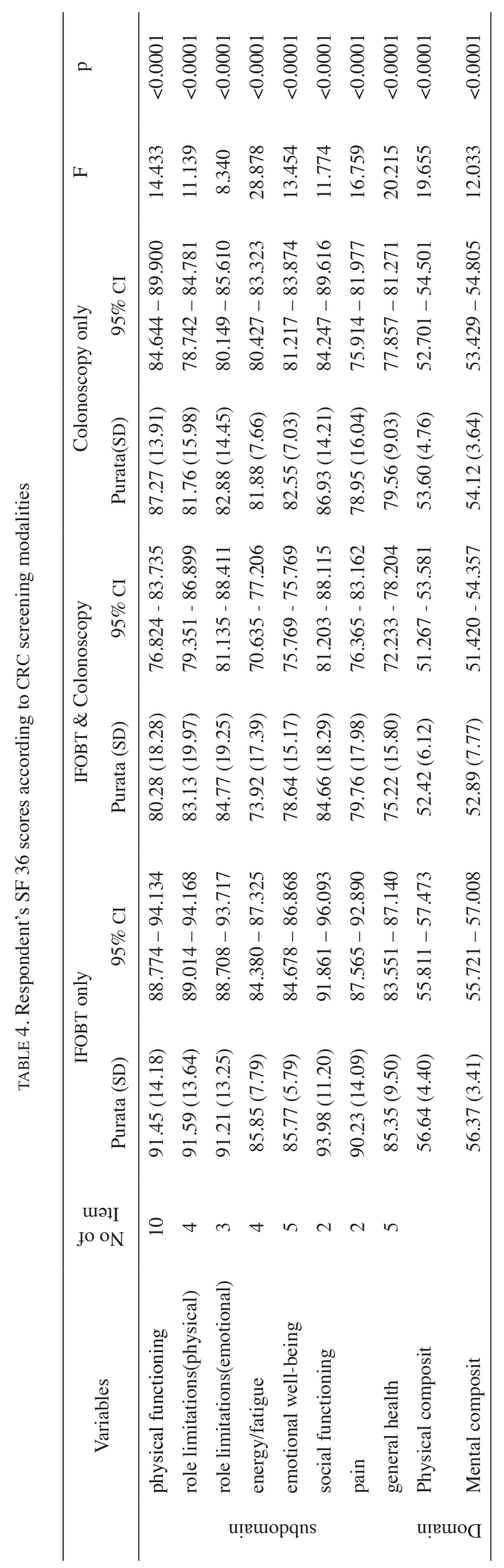


TABLE 5. Different in QOL from SF 36 by CRC screening modalities

\begin{tabular}{lcccccc}
\hline Modality & $\mathrm{n}$ & Mean score & $\mathrm{SD}$ & $95 \% \mathrm{CI}$ & $\mathrm{F}$ & $\mathrm{p}$ \\
\hline IFOBT only & 110 & 0.850 & 0.097 & $0.830-0.871$ & 21.505 & $<0.0001$ \\
IFOBT and colonoscopy & 110 & 0.772 & 0.124 & $0.749-0.795$ & & \\
Colonoscopy & 110 & 0.762 & 0.107 & $0.743-0.780$ & & \\
& 330 & 0.795 & 0.116 & $0.782-0.807$ & & \\
\hline
\end{tabular}

*one-way ANOVA

Post hoc analysis: the mean difference of modality is significant between IFOBT only and IFOBT \& colonoscopy; and between IFOBT only and colonoscopy only, but there is no significant between IFOBT \& colonoscopy and colonoscopy only

The majority of respondents in this study had underlying health problems $(75.2 \%)$. As the CRC screening program is still in the early stages of implementation in Malaysia, information on the program is still focused in health facilities causing limited exposure to among their clients only. Promotion, information and exposure on a large scale regarding the CRC screening programs should be implemented and delivered comprehensively to all levels of high risk community in order to achieve the target group and became a more effective program (Whyte \& Harnan 2014).

More than half of the respondents presented with CRC symptoms are among those from colonoscopy only modality. While majority respondents in IFOBT only modality and IFOBT and colonoscopy modality have no CRC symptoms. This study also shows that there were no CRC symptom in the respondents who have positive IFOBT or among high-risk groups of CRC such as familial adenomatous polyposis (FAP). Previous studies found that there were also non-compliance patients undergoing colonoscopy (31.9\%) (Hassan et al. 2016).

All respondents showed a high quality score of life. However, there were differences in respondents' QOL according to the CRC screening modalities. As CRC screening program is still in its early stages in Malaysia, there has been no previous local survey on the QOL of the population undergoing a CRC screening. Whereas previous studies at the international level regarding the CRC screening were more focused on QOL studies after the screening results were obtained and revealed (Kapidzic et al. 2012; Kirkoen et al. 2016).

Respondents from IFOBT only modality had higher scores in eight subdomain followed with IFOBT and colonoscopic modality and colonoscopy only modality except in the subdomain of physical function and social function. This study suggested that IFOBT only modality does not affect the respondents' QOL as the score of all SF-36 subdomains were very good and excellent. For colonoscopy's only modality, the SF-36 score was lower and at a fairly good level. This was influenced by the majority of respondents having underlying chronic health problems that affect their QOL and colonoscopy procedure further affected on their QOL. Meanwhile, in IFOBT and colonoscopy modality, the score of all subdomains decreases illustrating that IFOBT's positive results have affected the QOL respondents as they are in anxiety and affected with the need of undergoing colonoscopy (Ferrat et al. 2013).

The IFOBT's only modality had highest PCS, MCS and health utility scores and significant differences with other modalities. It also shows a higher PCS than MCS that illustrated better physical health than mental health of respondents. While in other modalities, the MCS is higher than the PCS describing that the mental health of the respondents are better than the physical health of the respondents. This shows that colonoscopy procedure do affect the physical effects of the respondents more than the mental effects and are inconsistent with the previous study that found mental health is affected more (Taupin et al. 2006).

The SF-36 health utility score in this study suggested that the general health status, QOL among IFOBT only modality respondents are in the best possible condition compared to other modalities. While respondents from IFOBT and colonoscopy modality have a better public health status than respondents of colonoscopy only modality. The general health status of the respondents in IFOBT only modality has the lowest negative effect followed by IFOBT modality and colonoscopy and the highest negative pressure on the colonoscopic only modality. In addition, this CRC screening program is a voluntary test and respondents are populations who are soaked with early screening and hope to get early treatment from the early detection of the disease.

The value of QOL among CRC screening individual in this study reflect the true value of QOL of the population as obtained directly from respondents. The respondents' selection criteria ensures that the QOL-related data is not affected by the CRC screening results. However, limited study location has effected to illustrate the overall CRC screening program in the country.

\section{CONCLUSION}

This study found that QOL in CRC screening individual in Malaysia is different among CRC screening modalities. The majority of CRC screening individual were in older age group and having underlying medical illness. They also presented with better physical health and mental health in IFOBT only modality compared to other modalities. Therefore, IFOBT only modality has the highest QOL and conducive and acceptable among community. This study 
identified IFOBT only modality as the most preferable choice of CRC screening modality among community for CRC screening program in Malaysia.

\section{ACKNOWLEDGEMENTS}

The authors thank Universiti Kebangsaan Malaysia (UKM) for funding this project through grant UKM-JEP-2016-015 and UKM Faculty of Medicine Fundamental Grant FF2016-037. Approval from the Ministry of Health, Malaysia is also obtained under code of NMRR- 15-1952-28360 (IIR). Our highest gratitude goes to Associate Professor Dr Raja Affendi bin Raja Ali, Department of Surgery UKMMC; Datuk Dr Muhammad Radzi Abu Hassan, Head of Department of Medical, Hospital Sultanah Bahiyah; Dr Ishak bin Hj Hussain, Health District Officer, Kota Setar Health District Office for their cooperation and facilitation during the data collection and to the hospital director for allowing us to conduct the study at their facilities.

\section{REFERENCES}

American Cancer Society. 2013. Colorectal Cancer Facts \& Figures 2011-2013 2006-2008.

Béjar, L.M., Gili, M., Infantes, B. \& Marcott, P.F. 2012. Incidence of colorectal cancer and influence of dietary habits in fifteen European countries from 1971 to 2002. Gaceta Sanitaria/ S.E.S.P.A.S 26(1): 69-73.

Brazier, E., Harper, R., Jones, N.M.B., Cathain, O., Thomas, K.J., Usherwood, T. \& Westlake, L. 1992. General practice validating the SF-36 health survey questionnaire: New outcome. BMJ British Medical Journal 305: 160-164.

Center, M.M., Jemal, A. \& Ward, E. 2009. International trends in colorectal cancer incidence rates. Cancer Epidemiology Biomarkers and Prevention 18(6): 1688-1694.

Department of Statistics Malaysia. 2016. Department of Statistics Malaysia Press Release Vital Statistics, Malaysia. 2016 (October). pp. 1-5.

Ezat, W.P. \& Aljunid, S. 2010. Cost-effectiveness of HPV vaccination in the prevention of cervical cancer in Malaysia. Asian Pac. J. Cancer Prev. 11(1): 79-90.

Ferrat, E., Breton, J.L., Veerabudun, K., Bercier, S., Brixi, Z., Khoshnood, B., Paillaud, E., Attali, C. \& Bastuji-Garin, S. 2013. Colorectal cancer screening: Factors associated with colonoscopy after a positive faecal occult blood test. British Journal of Cancer 109(6): 1437-1444.

Hassan, M.R.A., Leong, T.W., Andu, D.F.O., Hat, H. \& Nik Mustapha, N.R. 2016. Evaluation of a colorectal carcinoma screening program in Kota Setar and Kuala Muda districts, Malaysia. Asian Pacific Journal of Cancer Prevention 17: 569-573.

Hassan, M.R.A., Khazim, W.K.W., Othman, Z., Mustapha, N.R.N., Said, R.M., Leong, T.W., Suan, M.A.M. \& R, Mohd Said. 2014. The Second Annual Report of the National Cancer Patient Registry-Colorectal Cancer 2008-2013.

Hyodo, I., Suzuki, H., Takahashi, K., Saito, Y., Tanaka, S., Chiu, H-M., Kim, N.K., Li, J., Lim, R., Villalon, A. \& Boku, N. 2010. Present status and perspectives of colorectal cancer in Asia: Colorectal Cancer Working Group Report in 30th Asia-Pacific Cancer Conference. Jpn J. Clin. Oncol. 40(Supplement 1): i38-i43.
Imran, M.K. \& Ismail, A. 2010. Type 2 diabetes mellitus patients with poor glycaemic control have lower quality of life scores as measured by the Short Form-36. Singapore Medical 51: 157-162.

Institute of Health System Research. 2015. National Health and Morbidity Survey 2015. Journal of Chemical Information and Modeling Vol. 53.

International Agency for Research on Cancer World Health Organization. 2014. World Cancer Burden 2012. World Health Organization Vol. 2012.

Kapidzic, A., Korfage, I.J., van Dam, L., van Roon, H.C., Reijerink, J.C.I.Y., Zauber, G., van Ballegooijen, M., Kuipers, E.J. \& van Leerdam, M.E. 2012. Quality of life in participants of a CRC screening program. British Journal of Cancer 107: 1295-1301.

Kirkoen, B., Berstad, P., Botteri, E., Bernklev, L., El-Safadi, B., Hoff, G., De Lange, T. \& Bernklev, T. 2016. Psychological effects of colorectal cancer screening: Participants vs individuals not invited. World Journal of Gastroenterology 22(43): 9631-9641.

Leuraud, K., Jezewski-Serra, D., Viguier, J. \& Salines, E. 2013. Colorectal cancer screening by guaiac faecal occult blood test in France: Evaluation of the programme two years after launching. Cancer Epidemiology 37(6): 959-967.

Logan, R.F., Patnick, J., Nickerson, C., Coleman, L., Rutter, M.D. \& von Wagner, C. 2012. Outcomes of the Bowel Cancer Screening Programme (BCSP) in England after the first 1 million tests. Gut 61: 1439-1446.

Moss, S.M., Campbell, C., Melia, J., Coleman, D., Smith, S., Parker, R., Ramsell, P., Patnick, J. \& Weller, D.P. 2012. Performance measures in three rounds of the English bowel cancer screening pilot. Gut 61: 101-107.

National Cancer Registry Malaysia. 2011. National Cancer Registry Report Malaysia Cancer Statistics-Data and Figure 2007.

Ng, S.C. \& Wong, S.H. 2013. Colorectal cancer screening in Asia. British Medical Buletin 105: 29-42.

Norwati, D., Harmy, M.Y., Norhayati, M.N. \& Amry, R. 2014. Colorectal cancer screening practices of primary care providers: Results of a national survey in Malaysia. Asian Pacific Journal of Cancer Prevention: APJCP 15: 2901-2904.

RAND Medical Outcome Study. 1992. The MOS 36-item Short Form Health Survey scoring. RAND Corporation.

Redhwan, A.A., Idris, M.N., Zaleha, M.I., Robert, C., Fuad, I. \& Sami, R. 2008. Quality of life among women with breast cancer from Universiti Kebangsaan Malaysia Medical Centre, Malaysia. Journal of Community Health 14(2): 46-55.

Sararaks, S., Azman, B., Low, L.L., Rugayah, B., Hooi, L.N., Razak, M.A., Norhaya, M.R., Lim, K.B. \& Azian, A.A. 2005. Validity and reliability of the SF-36: The Malaysian context. Medical Journal of Malaysia 60(2): 163-179.

Shaukat, A., Mongin, S.J., Geisser, M.S., Lederle, F.A., Bond, J.H., Mandel, J.S. \& Church, T.R. 2013. Long-term mortality after screening for colorectal cancer. N. Engl. J. Med. 369: 1106-1114.

Steele, R.J.C., Kostourou, I., McClements, P., Watling, C., Libby, G., Weller, D., Brewster, D.H., Black, R., Carey, F.A. \& Fraser, C. 2010. Effect of gender, age and deprivation on key performance indicators in a FOBT-based colorectal screening programme. Journal of Medical Screening 17: 68-74.

Sung, J.J.Y., Lau, J.Y.W., Young, G.P., Sano, Y., Chiu, H.M., Byeon, J.S., Yeoh, K.G., Goh, K.L., Sollano, J., Rerknimitr, 
R., Matsuda, T., Wu11, K.C., Ng, S., Leung, S.Y., Makharia, G., Chong, V.H., Ho, K.Y., Brooks, D., Lieberman, D.A. \& Chan, F.K.L. 2008. Asia Pacific consensus recommendations for colorectal cancer screening. Gut 57(8): 1166-1176.

Taupin, D., Chambers, S.L., Corbett, M. \& Shadbolt, B. 2006. Colonoscopic screening for colorectal cancer improves quality of life measures: A population-based screening study. Health and Quality of Life Outcomes 4: 82.

UNESCO. Institute for Statistics. 2015. Malaysia - Literacy.

Whyte, S. \& Harnan, S. 2014. Effectiveness and costeffectiveness of an awareness campaign for colorectal cancer: A mathematical modeling study. Cancer Causes \& Control 25(6): 647-658.

Yusoff, H.M., Daud, N., Noor, N.M. \& Rahim, A.A. 2012. Participation and barriers to colorectal cancer screening in Malaysia. Asian Pacific Journal of Cancer Prevention 13: 3983-3987.

Intan Melati Abu Bakar*, Sharifa Ezat Wan Puteh \& Halim Ismail Department of Community Health

Faculty of Medicine

Universiti Kebangsaan Malaysia Medical Centre

Jalan Yaacob Latiff, Bandar Tun Razak Cheras

56000 Kuala Lumpur, Federal Territory

Malaysia
Raja Affendi Raja Ali

Department of Surgery, Faculty of Medicine

Universiti Kebangsaan Malaysia Medical Centre

Jalan Yaacob Latiff

Bandar Tun Razak Cheras

56000 Kuala Lumpur, Federal Territory

Malaysia

Muhammad Radzi Abu Hassan

Department of Medical

Hospital Sultanah Bahiyah

Km 6, Jalan Langgar

Bandar Alor Setar, 05460 Alor Setar

Kedah Darul Aman

Malaysia

*Corresponding author; email: iskandarintan@yahoo.com

Received: 25 January 2019

Accepted: 11 June 2019 